\title{
Analysis of Sodium and Potassium in Total Parenteral Nutrition Bags by ICP-MS and ICP-AES: Critical Influence of the Ingredients
}

\author{
Nicolas Marie ${ }^{1}$, Claire Verdier ${ }^{1}$, Barbara Le Bot ${ }^{2}$, Gwenola Burgot $^{3}$ \\ ${ }^{1}$ Department of Pharmacy, CHU de Rennes, Rennes, France \\ ${ }^{2}$ LERES, Ecole des Hautes Etudes en Santé Publique, Rennes, France \\ ${ }^{3}$ University of Rennes1, Faculty of Pharmacy, Rennes, France \\ E-mail: Gwenola.burgot@univ-rennes1.fr \\ Received June 2, 2011; revised July 1, 2011; accepted July 19, 2011
}

\begin{abstract}
The compounding of total parenteral nutrition solutions (TPN) in the hospital pharmacy is a high-risk activity for which a quality assurance programme is necessary. The complexity of parenteral nutrition solutions containing almost 50 ingredients makes it difficult to measure each of them. On the other hand, the assay of electrolytes such as sodium and potassium is accepted as a quality marker for estimating compounding errors. Thus, the aim of this study was to estimate the influence of ingredients on the accuracy of assays of electrolytes. Experiments were performed with aqueous working simulated solutions of sodium and potassium prepared by the addition of each nutrient step by step, (dextrose, amino acids, lipids, vitamins and trace elements). Sodium and potassium levels were measured by Inductively Coupled Plasma Mass Spectroscopy (ICP-MS) and Atomic Emission Spectroscopy (ICP-AES). The performance of these methods was compared using statistical evaluations (t-test and Mann-Whitney test). The study highlights the interference of amino acids, vitamins and trace elements when measuring sodium, but no interference was noted during the measurement of potassium. To reduce the risk and to improve the quality of compounding, we used an automated compounding device but, even in this case, the acceptance criterion for sodium and potassium determination was not $<10 \%$.
\end{abstract}

Keywords: Inorganic Cations, Electrolytes, Total Parenteral Nutrition, Atomic Emission Spectrometry

\section{Introduction}

The compounding of total parenteral nutrition (TPN) solutions in the hospital pharmacy is a high-risk activity for which a quality assurance programme is necessary $[1,2]$. The complexity of parenteral nutrition solutions containing almost 50 ingredients makes it difficult to measure each of them. Some TPN automated compounding device use electrical conductivity to check each solution type as it is transferred into the final bag [3]. But, there is not the case for all of device and moreover, there don't measure the quantity of ingredients. On the other hand, the assay of electrolytes such as sodium and potassium is accepted as an end-product quality assurance marker [4-7] with which to estimate compounding errors and moreover, the errors on them are potentially serious clinical consequences [8].
There are some widely used analytical techniques for sodium and potassium quantification that are based on atomic emission spectrometry (flame photometry), inductively coupled plasma atomic emission spectrometry (ICP-AES) or quadrupole mass spectrometry (ICP-MS), capillary electrophoresis coupled with indirect UV detector or with capacitively coupled contactless conductivity detection, ion chromatography and electrochemical methods with ion sensitive (selective) electrodes [9-16]. Some of them were developed for the analysis of inorganic cations in pharmaceutical solutions and TPN such as flame photometry, selective electrode and capillary electrophoresis $[5-7,17,18]$ but not always with successful results $[6,17,18]$. These results would be reliable to the fact that TPN have a high ionic force which product seriously distorted results for methods function activity and not concentration such as ion sensitive electrode. 
At our knowledge, no study was carried with ICP-AES or ICP-MS to determine the sodium and potassium concentration in TPN. ICP-AES and ICP-MS have found popularity in many fields. Numerous methods were developed and validated to determine sodium and potassium with ICP-AES and ICP-MS. These methods have been shown to be very attractive since they require a low sample volume and provide adequately low detection limits and the possibility of measurements after just a simple dilution step.

Also, it seems to us interesting to assess the performance of these methods with TPN and to estimate the influence of nutrient content on the accuracy of measurement of the sodium and potassium concentration. The overall aim is to improve the management process of end-product release by the hospital pharmacist during daily quality control.

\section{Methods-Experimental Data}

\subsection{Reagents}

All solutions were prepared with ultrapure water (18.2 Ohms) obtained by passing tap water through an RiOs 30 osmoseur and Milli-Q Gradient system (Millipore, St Quentin en Yvelines, France).

Acids were purchased from Carlo Erba (Val de Reuil,
France): Hydrochloric acid was $34 \%$ - 37\% superpure quality and nitric acid was $67 \%-69 \%$ super pure quality. Standard solutions of $\mathrm{Na}\left(1 \mathrm{~g} \cdot \mathrm{L}^{-1}\right.$ in $\left.0.07 \% \mathrm{HNO}_{3}\right)$ and $\mathrm{K}\left(1 \mathrm{~g} \cdot \mathrm{L}^{-1}\right.$ in $\left.0.1 \% \mathrm{HNO}_{3}\right)$ were purchased from Analab (Bischeim, France).

Water certified reference material from the National Institute of Standards and Technology (NIST 1643) was purchased from Techlab (Metz, France).

\subsection{Samples}

The composition of all components used for the parenteral nutrition solution is given in Table 1. We used 20\% sodium chloride solutions and $20 \%$ potassium chloride solutions, a commercial source of amino acid infusions: Vintène $^{\circledR}\left(20 \mathrm{~g} \cdot \mathrm{L}^{-1}\right.$ of nitrogen) and Vaminolact ${ }^{\circledR}\left(9.3 \mathrm{~g} \cdot \mathrm{L}^{-1}\right.$ of nitrogen) and dextrose infusion solutions (D50\%). Fat accounted for $30 \%$ of the standard distribution of nonprotein calories. Intravenous fat emulsions are made from vegetal oil and the phospholipids of eggs. In this study, we used Clinoléi ${ }^{\circledR} 20 \%$. Calcium gluconate injection $10 \%$ is the preferred form of calcium used in multicomponent parenteral nutrition formulations. Magnesium was used as a $15 \%$ magnesium sulphate injection. Phosphate was purchased as glycerophosphate sodium in Phocytan ${ }^{\circledR}$. The composition of trace elements and vitamins is given in Table 1.

Table 1. Qualitative and quantitative composition of reactives [19].

\begin{tabular}{|c|c|c|}
\hline & \multicolumn{2}{|c|}{ Amino acid solutions } \\
\hline & Vintène ${ }^{\circledR}$ & Vaminolact ${ }^{\circledR}$ \\
\hline L-Alanine & $1.3 \mathrm{~g}$ & $0.63 \mathrm{~g}$ \\
\hline L-Aspartic acid & $0.3 \mathrm{~g}$ & $0.41 \mathrm{~g}$ \\
\hline L-Cysteine chlorhydrate & $0.2 \mathrm{~g}$ & $0.1 \mathrm{~g}$ \\
\hline Glutamic acid & $0.5 \mathrm{~g}$ & $0.71 \mathrm{~g}$ \\
\hline L-Histidine & $0.4 \mathrm{~g}$ & $0.21 \mathrm{~g}$ \\
\hline L-Isoleucine & $0.7 \mathrm{~g}$ & $0.31 \mathrm{~g}$ \\
\hline L-Leucine & $1.4 \mathrm{~g}$ & $0.7 \mathrm{~g}$ \\
\hline L-Lysine & $1 \mathrm{~g}$ & $0.56 \mathrm{~g}$ \\
\hline L-Methionine & $0.7 \mathrm{~g}$ & $0.13 \mathrm{~g}$ \\
\hline L-Ornithine chlorhydrate & $0.1275 \mathrm{~g}$ & 0 \\
\hline L-Phenylalanine & $0.9 \mathrm{~g}$ & $0.27 \mathrm{~g}$ \\
\hline L-Serine & $0.3 \mathrm{~g}$ & $0.38 \mathrm{~g}$ \\
\hline L-Threonine & $0.55 \mathrm{~g}$ & $0.36 \mathrm{~g}$ \\
\hline L-Tryptophan & $0.25 \mathrm{~g}$ & $0.14 \mathrm{~g}$ \\
\hline L-Tyrosine & $0.04 \mathrm{~g}$ & $0.05 \mathrm{~g}$ \\
\hline L-Valine & $0.7 \mathrm{~g}$ & $0.36 \mathrm{~g}$ \\
\hline L-Taurine & 0 & $0.03 \mathrm{~g}$ \\
\hline Water for injection & To $100 \mathrm{~mL}$ & To $100 \mathrm{~mL}$ \\
\hline Total nitrogen & $20 \mathrm{~g} \cdot \mathrm{L}^{-1}$ & $9.3 \mathrm{~g} \cdot \mathrm{L}^{-1}$ \\
\hline Osmolarity & $1140 \mathrm{mOsm} \cdot \mathrm{L}^{-1}$ & $476 \mathrm{mOsm} \cdot \mathrm{L}^{-1}$ \\
\hline Manufacturer & Baxter & Fresenius Kabi France \\
\hline Excipients & $\begin{array}{l}\text { sodium hydrosulphite, } \\
\text { acetic acid, }\left[\mathrm{Na}^{+}\right]=0.32 \mathrm{~g} \cdot \mathrm{L}^{-1}\end{array}$ & $\begin{array}{l}\text { water for injectable preparations } \\
{\left[\mathrm{Na}^{+}\right]^{\mathrm{a}}<2 \mathrm{mg} \cdot \mathrm{L}^{-1} ;\left[\mathrm{K}^{+}\right]^{\mathrm{a}}<2 \mathrm{mg} \cdot \mathrm{L}^{-1}}\end{array}$ \\
\hline
\end{tabular}




\begin{tabular}{|c|c|c|c|c|}
\hline \multicolumn{3}{|c|}{ Dextrose solutions: Dextrose $50 \%$} & \multicolumn{2}{|c|}{$\operatorname{Decan}{ }^{\circledR} p$} \\
\hline Anhydrous dextrose & \multicolumn{2}{|l|}{$500 \mathrm{~g}$} & \multirow{2}{*}{$\begin{array}{l}\text { Gluconate ferreux } \\
\text { dihydrate }\end{array}$} & \\
\hline Water for injection & \multicolumn{2}{|l|}{ to $1000 \mathrm{~mL}$} & & \\
\hline $\mathrm{pH}$ & \multicolumn{2}{|l|}{3.6} & \multicolumn{2}{|l|}{ Copper gluconate } \\
\hline Caloric intake & \multicolumn{2}{|l|}{$2000 \mathrm{kcal} \cdot \mathrm{L}^{-1}$} & \multirow{2}{*}{\multicolumn{2}{|c|}{$\begin{array}{l}\text { Manganese gluconate } \\
\text { dihydrate }\end{array}$}} \\
\hline Osmolarity & \multicolumn{2}{|l|}{$2775 \mathrm{mOsm} \cdot \mathrm{L}^{-1}$} & & \\
\hline Manufacturer & \multicolumn{2}{|l|}{ Aguettant } & \multirow{2}{*}{\multicolumn{2}{|c|}{$\begin{array}{l}\text { Zinc gluconate trihydrate } \\
\text { Fluorure sodium }\end{array}$}} \\
\hline \multicolumn{3}{|c|}{ Lipids $=$ Clinoléic ${ }^{\circledR}$} & & \\
\hline Refined olive oil & \multicolumn{2}{|l|}{$16 \mathrm{~g}$} & \multirow{2}{*}{\multicolumn{2}{|c|}{ Cobalt gluconate }} \\
\hline Refined soya oil & \multicolumn{2}{|l|}{$4 \mathrm{~g}$} & & \\
\hline Water for injection & \multicolumn{2}{|l|}{ to $100 \mathrm{~mL}$} & \multicolumn{2}{|l|}{ Selenite sodium } \\
\hline Excipients & \multicolumn{2}{|c|}{$\begin{array}{l}\text { egg phosphatide, glycerol, sodium } \\
\text { oleate and sodium hydroxide }\end{array}$} & \multicolumn{2}{|l|}{ Sodium iodure } \\
\hline Osmolarity of dispersive phase & \multicolumn{2}{|c|}{$270 \mathrm{mOsm} \cdot \mathrm{L}^{-1}$} & \multirow{2}{*}{\multicolumn{2}{|c|}{$\begin{array}{l}\text { Chrome chlorure } \\
\text { hexahydrate }\end{array}$}} \\
\hline Caloric intake & \multicolumn{2}{|l|}{$2000 \mathrm{kcal} \cdot \mathrm{L}^{-1}$} & & \\
\hline \multirow[t]{2}{*}{ Manufacturer } & \multicolumn{2}{|l|}{ Baxter } & \multicolumn{2}{|l|}{ Ammonium molybdate } \\
\hline & Electrolytes & Manufacturer & 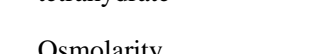 & 176 \\
\hline Calcium gluconate $10 \% 10$ mL & {$\left[\mathrm{Ca}^{2+}\right]=0.22 \mathrm{~mol} \cdot \mathrm{L}^{-1}$} & Renaudin & Usinvidnity & \\
\hline $\mathrm{NaCl} 20 \% 500 \mathrm{~mL}$ & {$\left[\mathrm{Na}^{+}\right]=[\mathrm{Cl}]=3.42 \mathrm{~mol} \cdot \mathrm{L}^{-1}$} & Renaudin & Sodium ${ }^{a}$ & \\
\hline $\mathrm{KCl} 20 \% 500 \mathrm{~mL}$ & {$\left[\mathrm{~K}^{+}\right]=2.68 \mathrm{~mol} \cdot \mathrm{L}^{-1}$} & Renaudin & Potassium $^{\mathrm{a}}$ & \\
\hline Magnesium sulphate $15 \% 10$ mL & {$\left[\mathrm{Mg}^{2^{+}}\right]=0.61 \mathrm{~mol} \cdot \mathrm{L}^{-1}$} & Renaudin & Manufacturer & $A$ \\
\hline Phocytan ${ }^{\circledR} 100 \mathrm{~mL}$ & $\begin{array}{l}{\left[\mathrm{Na}^{+}\right]^{\mathrm{a}}=0.66 \mathrm{~mol} \cdot \mathrm{L}^{-1}} \\
{[\text { dextrose }]=0.33 \mathrm{~mol} \cdot \mathrm{L}^{-1}} \\
\text { [phosphates }=0.33 \mathrm{~mol} \cdot \mathrm{L}^{-1}\end{array}$ & Aguettant & Excipients & $\begin{array}{r}\text { water } \\
\text { glucon } \\
\end{array}$ \\
\hline${ }^{\mathrm{a}}$ value determin ed by ICP-AES in ou & ur laboratory & & avalue determin ed by ICP-AE & in our lab \\
\hline & Cernevit & er vial $5 \mathrm{~mL}$ (lyo & ate) & \\
\hline & Vitamin A & & $3500 \mathrm{UI}$ & \\
\hline & Vitamin B1 & & $3.51 \mathrm{mg}$ & \\
\hline & Vitamin B2 & & $4.14 \mathrm{mg}$ & \\
\hline & Vitamin B5 & & $17.25 \mathrm{mg}$ & \\
\hline & Vitamin B6 & & $4.53 \mathrm{mg}$ & \\
\hline & Vitamin B8 & & $0.069 \mathrm{mg}$ & \\
\hline & Vitamin B9 & & $0.414 \mathrm{mg}$ & \\
\hline & Vitamin B12 & & $0.006 \mathrm{mg}$ & \\
\hline & Vitamin C & & $125 \mathrm{mg}$ & \\
\hline & Vitamin D2 & & & \\
\hline & Vitamin D3 & & $220 \mathrm{UI}$ & \\
\hline & Vitamin E & & $11.2 \mathrm{UI}$ & \\
\hline & Vitamin K1 & & & \\
\hline & Vitamin PP & & $46 \mathrm{mg}$ & \\
\hline & Sodium $^{\mathrm{a}}$ & & $22.84 \mathrm{mg}$ & \\
\hline & Potassium $^{\mathrm{a}}$ & & $<10 \mu \mathrm{g}$ & \\
\hline & Manufacturer & & Baxter & \\
\hline
\end{tabular}

${ }^{a}$ value determined by ICP-AES in our laboratory 
Working solutions or simulated electrolyte solutions were prepared in the laboratory by mixing a fixed sodium chloride and potassium chloride concentration (Table 2) with each nutrient likely to interfere step by step. Mixing is made manually or automated compounding device BAXA $^{\circledR}$; for each nutrient, the ratios of concentration were in the same proportion as in typically prescribed parenteral nutrition solutions. The standard distribution of non-protein calories is $70 \%$ as carbohydrate and $30 \%$ as fat.

\subsection{Preparation of Standards and Diluted Samples}

Standard calibration solutions were prepared from $1 \mathrm{~g} \cdot \mathrm{L}^{-1}$ single elements by mixture and dilution in ultrapure water acidified with $1 \% \mathrm{HNO}_{3}$ and $0.5 \% \mathrm{HCl}$. Sequential dilution was performed and five different concentration levels were obtained as follows: $0,2,5,10,25^{\circ}$ and 50 $\mathrm{mg} \cdot \mathrm{L}^{-1}$ for ICP-AES external calibration quantification.

Samples were diluted to $1 / 50,1 / 100$ and $1 / 200$ with ultrapure water acidified with $1 \% \mathrm{HNO}_{3}$ and $0.5 \% \mathrm{HCl}$. Standard added procedure analysis consisted of adding $2.5 \mathrm{ml}$ of $\mathrm{Na}\left(1 \mathrm{~g} \cdot \mathrm{L}^{-1}\right)$ and $2.5 \mathrm{ml}$ of $\mathrm{K}\left(1 \mathrm{~g} \cdot \mathrm{L}^{-1}\right)$ to $100 \mathrm{ml}$ of sample. After three sequential dilutions of this added sample $(2 / 5 ; 1 / 5 ; 2 / 25)$, the resulting four samples and a control sample were analysed in ICP-AES. Calibration curves were used to quantify the sample.

\subsection{Instrumentation}

\subsubsection{ICP-MS}

An Agilent 7500ce ORS ICP-MS system equipped with an auto sampler (CETAC ASX-510), a micro flow nebulizer, a Scott chamber and a quartz ICP torch was used. During the analysis the following procedure was followed: optimization of the instrument, calibration with the standard solutions, analysis of the sample blank consisting of $1 \%$ nitric acid and $0.5 \%$ chlorhydric acid, analysis of the reference material (NIST 1643), and samples with one level calibration point and a blank after every 10 samples. The isotopes and gas reaction mode were as follows: for $\mathrm{Na}$ analysis, mass 23 (mode helium), and for $\mathrm{K}$ analysis, mass 39 (mode helium)

Samples were quantified with ICP-MS with external calibration on a $1 / 200$ sample dilution. The ICP-MS operating conditions and measurement parameters are given in Table 3.

Table 2. Preparation of the working solutions.

\begin{tabular}{|c|c|c|c|c|c|c|c|c|c|c|c|c|c|c|}
\hline & $\begin{array}{c}N^{\circ} \\
\text { mixture }\end{array}$ & $\begin{array}{c}{\left[\mathrm{Na}^{+}\right]} \\
\left(\mathrm{mmol} \cdot \mathrm{L}^{-1}\right)\end{array}$ & $\begin{array}{l}\text { Volume } \\
\mathrm{NaCl} 20 \% \\
(\mathrm{~mL})\end{array}$ & $\begin{array}{c}{\left[K^{+}\right]} \\
\left(\mathrm{mmol} \cdot \mathrm{L}^{-1}\right)\end{array}$ & $\begin{array}{c}\text { Volume } \\
\text { KCl 10\% } \\
(\mathrm{mL})\end{array}$ & $\begin{array}{c}N \\
\left(\mathrm{~g} \cdot \mathrm{L}^{-1}\right)\end{array}$ & $\begin{array}{c}\text { Volume } \\
\text { Vintène } \\
\text { (mL) }\end{array}$ & $\begin{array}{l}\text { Lipids } \\
\left(\mathrm{g} \cdot \mathrm{L}^{-1}\right)\end{array}$ & $\begin{array}{l}\text { Volume } \\
\text { Clinoleic } \\
\text { (mL) }\end{array}$ & $\begin{array}{c}\text { Dextrose } \\
\left(\mathrm{g} \cdot \mathrm{L}^{-1}\right)\end{array}$ & $\begin{array}{l}\text { Volume } \\
\text { D50\% } \\
\text { (mL) }\end{array}$ & $\begin{array}{l}\text { Volume } \\
\text { Cernevit } \\
\text { (mL) }\end{array}$ & $\begin{array}{c}\text { Volume } \\
\text { TE } \\
\text { (mL) }\end{array}$ & Water \\
\hline ions & 1 & 50 & 1.46 & 10 & 0.746 & 0 & 0 & 0 & 0 & 0 & 0 & 0 & 0 & To $100 \mathrm{~mL}$ \\
\hline ions $+\mathrm{D}^{\mathrm{a}}$ & 2 & 50 & 1.46 & 10 & 0.746 & 0 & 0 & 0 & 0 & 150 & 30 & 0 & 0 & To $100 \mathrm{~mL}$ \\
\hline ions $+\mathrm{AA}^{\mathrm{a}}$ & 3 & 50 & 1.46 & 10 & 0.746 & 4 & 20 & 0 & 0 & 0 & 0 & 0 & 0 & To $100 \mathrm{~mL}$ \\
\hline ions $+\mathrm{L}^{\mathrm{a}}$ & 4 & 50 & 1.46 & 10 & 0.746 & 0 & 0 & 40 & 20 & 0 & 0 & 0 & 0 & To $100 \mathrm{~mL}$ \\
\hline ions $+\mathrm{D}^{\mathrm{a}}+\mathrm{AA}^{\mathrm{a}}$ & 5 & 50 & 1.46 & 10 & 0.746 & 4 & 20 & 0 & 0 & 150 & 30 & 0 & 0 & To $100 \mathrm{~mL}$ \\
\hline ions $+\mathrm{D}^{\mathrm{a}}+\mathrm{L}^{\mathrm{a}}$ & 6 & 50 & 1.46 & 10 & 0.746 & 0 & 0 & 40 & 20 & 150 & 30 & 0 & 0 & To $100 \mathrm{~mL}$ \\
\hline ions $+\mathrm{AA}^{\mathrm{a}}+\mathrm{L}^{\mathrm{a}}$ & 7 & 50 & 1.46 & 10 & 0.746 & 4 & 20 & 40 & 20 & 0 & 0 & 0 & 0 & To $100 \mathrm{~mL}$ \\
\hline $\begin{array}{l}\text { ions }+\mathrm{D}^{\mathrm{a}}+ \\
\mathrm{AA}^{\mathrm{a}} \\
+\mathrm{L}^{\mathrm{a}}=\text { ternaire }\end{array}$ & 8 & 50 & 1.46 & 10 & 0.746 & 4 & 20 & 40 & 20 & 150 & 30 & 0 & 0 & To $100 \mathrm{~mL}$ \\
\hline $\begin{array}{l}\text { ternaire }+ \text { Vit }^{\mathrm{a}} \\
+\mathrm{TE}^{\mathrm{a}}\end{array}$ & 9 & 50 & 1.46 & 10 & 0.746 & 4 & 20 & 40 & 20 & 150 & 30 & 5 & 20 & To $100 \mathrm{~mL}$ \\
\hline
\end{tabular}

${ }^{\mathrm{a}} \mathrm{D}=$ dextrose, $\mathrm{AA}=$ amino acids, $\mathrm{L}=$ lipids, vit = vitamins, $\mathrm{TE}=$ trace elements

Table 3. ICP-MS operating conditions and measurement parameters.

\begin{tabular}{lc}
\hline Rf generator & $27.12 \mathrm{MHz}$ \\
Rf power & $1550 \mathrm{~W}$ \\
Sampling depth & $8.2 \mathrm{mn}$ \\
Carrier gas flow rate (Ar) & $0.8 \mathrm{~L} \cdot \mathrm{min}^{-1}$ \\
Auxiliary (make up) gas flow rate (Ar) & $0.28 \mathrm{~L} \cdot \mathrm{min}^{-1}$ \\
He gas flow rate & $5 \mathrm{ml} \cdot \mathrm{min}^{-1}$ \\
Integration time & $0.1 \mathrm{~s}$ \\
Nebulizer pump & $0.08 \mathrm{rps}$ \\
Acquisition mode & He mode \\
Quadruple bias & $-3(\mathrm{~V})$ \\
\hline
\end{tabular}




\subsubsection{ICP-AES}

An Activa instrument (Horiba Jobin Yvon, Longjumeau, France) equipped with an autosampler AS500 (Horiba Jobin Yvon, Longjumeau, France), a tangential nebulizer (Miramist Peek Body), a cyclonic spray chamber, a radial torch, a Czerny-Turner monochromator, and an optical path purged with nitrogen was used. The daily calibration of the monochromator was performed by using the carbon emission lines and each operating wavelength was individually centred before the experiment began. Three wavelengths were chosen for Na analysis: 330.237, 588.995 and $589.592 \mathrm{~nm}$ and two wavelengths for $\mathrm{K}$ analysis: 766.49 and $769.898 \mathrm{~nm}$. The ICP-AES operating conditions are given in Table 4.

Samples were quantified with ICP-AES three times, first with external calibration of the 1/50 sample dilution, and then with the standard added procedure on the 1/50 sample dilution and 1/100 sample dilution.

The performance of the methods was compared using statistical evaluations: t-test and Mann-Whitney test. A maximum risk of $5 \%$ of the measures outside the acceptance limits was considered statistically significant.

\section{Results and Discussion}

In the first experiment, we compare the quality of the results obtained from the vials of sodium chloride and potassium chloride used for compounding parenteral nutrition diluted using manually laboratory practice and using the automated compounding system BAXA ${ }^{\circledR}$.

This step is followed by a dilution in ultrapure water acidified with $1 \% \mathrm{HNO}_{3}$ and $0.5 \% \mathrm{HCl}$ according the ICP-MS procedure currently used by our laboratory (LERES). The volume of sample, sodium chloride and potassium chloride solution, is very weak. Thus, it doesn't affect the ability of the ICP-MS method to provide accu- rate results.

In this case, the total measurement error of the results is related to the trueness of the manufacturing products, the dilution for working solutions and for ICP-MS procedure and the error on the analytical procedure.

The results obtained by ICP-MS are given in Table 5 . We also tested a solution of Phocytan ${ }^{\circledR}$, which contains glycerophosphate sodium and a blend of sodium chloride or glycerophosphate solutions with potassium chloride solution, to determine whether or not these solutions interfere with the quality of the results.

The results show that the analytical performance, in terms of trueness and precision, was identical for the solutions prepared by each method (manually with laboratory instruments or automated compounding system BAXA $^{\circledR}$ ). The results are shown as the average obtained after measuring the sample five times. Table 5 shows that the bias was between -2.6 and $2.1 \%$ and the precision range was $<1.6 \%$, which means that the measurement of electrolytes showed sufficient accuracy for the determination of sodium and potassium in our study with step by step complement. The results obtained on mixtures of sodium and potassium are also consistent with a bias of between $-3.4 \%$ and $0.2 \%$ and a precision range between $1 \%$ and $5 \%$.

Table 6 shows the results obtained for working solutions prepared by mixing some fixed sodium and potassium concentrations $\left(50 \mathrm{mmol} \cdot \mathrm{L}^{-1}\right.$ and $10 \mathrm{mmol} \cdot \mathrm{L}^{-1} \mathrm{re}-$ spectively) with each nutrient likely to interfere step by step. The sodium and potassium concentrations were carefully chosen as the most frequently used in our total parenteral nutrition compounding The nutrients were added one by one and then mixed. For these determinations, we tested the performance of four analytical methods: external calibration ICP-AES (dilution 1/50), spiked ICP-AES with two dilutions (1/100 and 1/50) and

Table 4. ICP-AES operating conditions and measurement parameters.

\begin{tabular}{ll}
\hline ICP-source & \\
Power & $1000 \mathrm{~W}$ \\
Argon flow rate & $12 \mathrm{~L} \cdot \mathrm{min}^{-1}$ \\
Coating gas flow rate & $0.2 \mathrm{~L} \cdot \mathrm{min}^{-1}$ \\
Generator type & $\mathrm{JY} 2501$ \\
Monochromateur & \\
Wavelength range & $165-800 \mathrm{~nm}$ \\
Optical bench temperature & $31.5^{\circ} \mathrm{C}$ \\
Focal length & $0.64 \mathrm{~m}$ \\
Grating number 1 & 4343 grooves $\cdot \mathrm{mm}^{-1}$ \\
Grating number 2 & $2400 \mathrm{grooves}^{-1} \mathrm{~mm}^{-1}$ \\
Entrance slit 1 & $10 \mu \mathrm{m}$ \\
Entrance slit 2 & $20 \mu \mathrm{m}$ \\
Nitrogen flow rate & $3 \mathrm{~L} \cdot \mathrm{min}^{-1}$ \\
\hline
\end{tabular}


Table 5. Sodium and potassium levels measured by ICP-MS.

\begin{tabular}{|c|c|c|c|c|c|c|c|}
\hline Pharmaceutical product & $\begin{array}{l}\mathrm{NaCl} \text { vial } \\
78.66 \mathrm{~g} \cdot \mathrm{L}^{-1}\end{array}$ & $\begin{array}{c}\text { KCl vial } \\
52.42 \mathrm{~g} \cdot \mathrm{L}^{-1}\end{array}$ & $\begin{array}{c}\text { NaCl contained in } \\
\text { Phocytan } \\
15.18 \mathrm{~g} \cdot \mathrm{L}^{-1}\end{array}$ & \multicolumn{2}{|c|}{$\begin{array}{c}\mathrm{NaCl} \text { vial } \\
+ \\
\mathrm{KCl} \text { vial }\end{array}$} & \multicolumn{2}{|c|}{$\begin{array}{c}\text { NaCl contained in phocytan } \\
+ \\
\text { KCl vial }\end{array}$} \\
\hline $\begin{array}{l}\text { Ion assay Theorical value } \\
\text { of diluted solution }\left(\mathrm{mg} \cdot \mathrm{L}^{-1}\right)\end{array}$ & 1150 & 391 & 1150 & 1150 & 391 & 1150 & 391 \\
\hline \multicolumn{8}{|c|}{ manually compounded with analytical instrumentation } \\
\hline Mean & 1136 & 399 & 1149 & 1113 & 382 & 1151 & 391 \\
\hline S.D. & 18 & 5.11 & 10.21 & 49.81 & 18.42 & 18.38 & 6.31 \\
\hline $\mathrm{CV}$ & 1.58 & 1.28 & 0.88 & 4.47 & 4.81 & 1.59 & 1.6 \\
\hline Bias & -1.15 & 2.09 & -0.75 & -3.15 & -2.15 & 0.12 & 0.2 \\
\hline \multicolumn{8}{|c|}{ Baxa ${ }^{\circledR}$ compounded } \\
\hline S.D. & 18.36 & 5.81 & 8.07 & 6.8 & 2.13 & 9.68 & 6.09 \\
\hline $\mathrm{CV}$ & 1.58 & 1.52 & 0.69 & 0.61 & 0.56 & 0.85 & 1.6 \\
\hline bias & 1.11 & -2.51 & 1.48 & -2.57 & -3.37 & -0.59 & -3.1 \\
\hline
\end{tabular}

ICP-MS (dilution 1/200). No difference was observed between the four methods according to the Student and Mann-Whitney test, although better results appeared to be obtained by external calibration ICP-AES (dilution $1 / 50)$.

The results obtained by these four methods (Table 6) highlight the interference of amino acids, vitamins and trace elements in sodium determination, but no interference was noted in the potassium assay. The error was only systematic since all precision results were correct. Student and Mann-Whitney tests confirmed this hypothesis. These studies indicate that potassium assay is a better marker for quality insurance.

We also considered the composition of bulk products. Vintene ${ }^{\circledR}$ solution contains $14 \mathrm{mmol} \cdot \mathrm{L}^{-1}$ of sodium according to available technical information [20]. The determination of sodium by ICP-AES confirmed that the quantity of sodium in the solution of amino acids (Vaminolact $^{\circledR}$ ) is negligible $<2 \mathrm{mg} \cdot \mathrm{L}^{-1}$. For vitamins $\left(\right.$ Cernevit $^{\circledR}$ ) and trace elements (Decan ${ }^{\circledR}$ ) the sodium content is much higher, with $22.84 \mathrm{mg}$ in each $5 \mathrm{ml}$ vial of Cernevit ${ }^{\circledR}$ and $1.86 \mathrm{mg}$ in each $40 \mathrm{ml}$ vial of Decan ${ }^{\circledR}$. As a result, the bias in the determination of sodium in the mixes containing vitamins and trace elements was wrong, at $19.71 \%$ instead of $-0.96 \%$ after correction. The problem was the same with the Vintene ${ }^{\circledR}$ solutions.

Using these values for correcting the results of Table 6, trueness was improved and was always smaller than $6.1 \%$. We thus recommend estimating the content of sodium and potassium in pharmaceutical supplies before building an analytical procedure to control the quality of parenteral nutrition solutions. We have noted in a previous study the same problem for the determination of calcium in TPN [21].
Moreover, we also tested the impact of ultrafiltration on the performance of the methods owing to the fact TPN contains lipids. No significant difference was noted (Table 7).

The value of the acceptability limit is not arbitrary but depends on the objectives of the analytical procedure. For instance, when expressed as a percent of the target value, it may be $1 \%$ for bulk materials, $5 \%$ for the active ingredient in an end-product pharmaceutical, and 15\% for biological samples [22-24]. The difficulty in defining the acceptability criterion for parenteral nutrition solutions comes from the fact that the solution is an extemporaneously pharmaceutical preparation that is as complex as biological samples. In fact, some authors take as the acceptability criterion for the assay of electrolytes at $+/-15 \%$. According to our results we consider that it would be possible to define the acceptability criterion for the assay of electrolytes by ICP-MS and ICP-AES at $+/-10 \%$. Ehling et al. [25] had given the same value of acceptability limit for measure of sodium in foods by ICP-MS.

\section{Conclusions}

The compounding of total parenteral nutrition solutions in the hospital pharmacy is a high-risk activity. The management process of preparation release involves the routine analysis of electrolytes that are good quality markers for the overall compounding practice. Moreover, they are a key component of a quality assurance programme because their variability may be responsible for severe problems in patients.

Our study highlights the need to verify the effect of the contents of the pharmaceutical supplies on the results. 
Table 6. Levels of sodium and potassium measured by ICP-AES and ICP-MS in experiments in which each nutrient was added step by step.

\begin{tabular}{|c|c|c|c|c|c|c|c|c|}
\hline \multirow{3}{*}{ Compounds } & \multirow{3}{*}{$\begin{array}{l}\text { Theoretical value } \\
\left(\mathrm{mg} \cdot \mathrm{L}^{-1}\right)\end{array}$} & \multicolumn{2}{|c|}{$\begin{array}{l}\text { ICP AES External } \\
\text { Calibration } \\
\text { 1/50 dilution }\end{array}$} & \multicolumn{2}{|c|}{$\begin{array}{c}\text { ICP AES } \\
\text { Standard added } \\
\text { 1/100 dilution }\end{array}$} & \multirow{3}{*}{$\begin{array}{c}\text { ICP AES } \\
\text { Standard added } \\
\text { 1/50 dilution } \\
\mathrm{K} \\
391\end{array}$} & \multicolumn{2}{|c|}{$\begin{array}{c}\text { ICP MS } \\
\text { External calbration } \\
1 / 200 \text { dilution }\end{array}$} \\
\hline & & $\mathrm{Na}$ & $\mathrm{K}$ & $\mathrm{Na}$ & $\mathrm{K}$ & & $\mathrm{Na}$ & $\mathrm{K}$ \\
\hline & & 1150 & 391 & 1150 & 391 & & 1150 & 391 \\
\hline \multirow{4}{*}{$\begin{array}{l}\text { Ions + water for } \\
\text { injection }\end{array}$} & Mean $\left(\mathrm{mg} \cdot \mathrm{L}^{-1}\right)$ & 1092.37 & 366.5 & 1210 & 386.5 & 397.5 & 1157 & 368 \\
\hline & SD & 19.64 & 3.54 & 30.00 & 9.19 & 10.61 & & \\
\hline & RSD & 1.80 & 0.96 & 2.48 & 2.38 & 2.67 & & \\
\hline & bias & -5.01 & -6.27 & 5.22 & -1.15 & 1.66 & 0.61 & -5.88 \\
\hline \multirow{4}{*}{$\begin{array}{l}\text { Ions }+ \text { dextrose } \\
\left(150 \mathrm{~g} \cdot \mathrm{L}^{-1}\right)\end{array}$} & Mean $\left(\mathrm{mg} \cdot \mathrm{L}^{-1}\right)$ & 1094.37 & 363.8 & 1206.67 & 377.5 & 384 & 1164 & 378 \\
\hline & SD & 11.41 & 2.47 & 15.28 & 14.85 & 2.12 & & \\
\hline & RSD & 1.04 & 0.68 & 1.27 & 3.93 & 0.55 & & \\
\hline & bias & -4.84 & -6.97 & 4.93 & -3.45 & -1.79 & 1.22 & -3.32 \\
\hline \multirow{6}{*}{$\begin{array}{c}\text { Ions }+\mathrm{AA}^{\mathrm{a}} \\
\left(4 \mathrm{~g} \cdot \mathrm{L}^{-1}\right)\end{array}$} & Mean $\left(\mathrm{mg} \cdot \mathrm{L}^{-1}\right)$ & 1192.98 & 370 & 1256.67 & 368 & 381.75 & 1238 & 375 \\
\hline & Mean corrected & 1128.58 & - & 1192.27 & - & & 1173.6 & - \\
\hline & SD & 10.26 & 1.41 & 41.63 & 7.07 & 8.84 & & \\
\hline & RSD & 0.86 & 0.38 & 3.31 & 1.92 & 2.32 & & \\
\hline & Bias & 3.74 & -5.37 & 9.28 & -5.88 & -2.37 & 7.65 & -4.09 \\
\hline & Bias corrected & -1.86 & - & 3.68 & - & - & 2.05 & - \\
\hline \multirow{4}{*}{$\begin{array}{l}\text { Ions }+ \text { Lipids } \\
\left(40 \mathrm{~g} \cdot \mathrm{L}^{-1}\right)\end{array}$} & Mean $\left(\mathrm{mg} \cdot \mathrm{L}^{-1}\right)$ & 1179.7 & 376 & 1206.67 & 378.5 & 397 & 1172 & 380 \\
\hline & $\mathrm{SD}$ & 37.85 & 7.07 & 15.28 & 6.36 & 4.95 & & \\
\hline & RSD & 3.21 & 1.88 & 1.27 & 1.68 & 1.25 & & \\
\hline & bias & 2.58 & -3.84 & 4.93 & -3.20 & 1.53 & 1.91 & -2.81 \\
\hline \multirow{6}{*}{$\begin{array}{c}\text { Ions + } \mathrm{D}^{\mathrm{a}}(150 \mathrm{~g} / \mathrm{L}) \\
+\mathrm{AA}(4 \mathrm{~g} / \mathrm{L})\end{array}$} & Mean $\left(\mathrm{mg} \cdot \mathrm{L}^{-1}\right)$ & 1204.08 & 373.5 & 1276.67 & 386.5 & 401.75 & 1250 & 375 \\
\hline & Mean corrected & 1139.7 & - & 1212.27 & - & - & 1185.6 & -4.09 \\
\hline & SD & 13.17 & 0.71 & 20.62 & 4.95 & 4.60 & & - \\
\hline & RSD & 1.09 & 0.19 & 1.63 & 1.28 & 1.14 & & \\
\hline & Bias & 4.70 & -4.48 & 11.01 & $-1,15$ & 2.75 & 8.7 & \\
\hline & Bias corrected & -0.9 & - & 5.41 & & - & 3.1 & \\
\hline \multirow{4}{*}{$\begin{array}{l}\text { Ions }+D^{\mathrm{a}}\left(150 \mathrm{~g} \cdot \mathrm{L}^{-1}\right) \\
+ \text { Lipids }\left(40 \mathrm{~g} \cdot \mathrm{L}^{-1}\right)\end{array}$} & Mean $\left(\mathrm{mg} \cdot \mathrm{L}^{-1}\right)$ & 1154.43 & 379 & 1183.33 & 370 & 389.75 & 1211 & 384 \\
\hline & $\mathrm{SD}$ & 8.04 & 0.71 & 28.87 & 15.56 & 4.60 & & \\
\hline & RSD & 0.70 & 0.19 & 2.44 & 4.20 & 1.18 & & -1.79 \\
\hline & bias & 0.39 & -3.07 & 2.90 & -5.37 & -0.32 & 5.3 & \\
\hline \multirow{6}{*}{ Ions + vit $^{\mathrm{a}}+\mathrm{TE}^{\mathrm{a}}$} & Mean $\left(\mathrm{mg} \cdot \mathrm{L}^{-1}\right)$ & 1376.68 & 373 & 1400.00 & 368 & 389.5 & 1355 & 365 \\
\hline & Mean corrected & 1138.98 & - & 1162.3 & - & - & 1117.3 & - \\
\hline & $\mathrm{SD}$ & 10.62 & 3.54 & 34.64 & 8.49 & 4.95 & & \\
\hline & RSD & 0.77 & 0.95 & 2.47 & 2.31 & 1.27 & & \\
\hline & Bias & 19.71 & -4.60 & 21.74 & -5.88 & -0.38 & 17.83 & 6.65 \\
\hline & Bias corrected & -0.36 & - & 1.07 & - & - & -7.84 & - \\
\hline \multirow{6}{*}{$\begin{array}{c}\text { Ions + } \text { AA }^{\text {a }}(4 \mathrm{~g} / \mathrm{L}) \\
\text { + lipids }(40 \mathrm{~g} / \mathrm{L})\end{array}$} & Mean $\left(\mathrm{mg} \cdot \mathrm{L}^{-1}\right)$ & 1255.98 & 383.8 & 1273.33 & 381.5 & 399.25 & 1282 & 388 \\
\hline & Mean corrected & 1191.58 & - & 1208.93 & - & - & 1217.6 & - \\
\hline & $\mathrm{SD}$ & 6.02 & 1.06 & 40.11 & 17.88 & 4.60 & & \\
\hline & RSD & 0.46 & 0.28 & 3.17 & 4.63 & 1.15 & & \\
\hline & Bias & 9.22 & -1.85 & 10.72 & -2.43 & 2.11 & 11.48 & -0.77 \\
\hline & Bias corrected & 3.62 & - & 5.12 & - & - & 5.88 & - \\
\hline \multirow{6}{*}{ Ions $+\mathrm{D}^{\mathrm{a}}+\mathrm{AA}+$ lipids } & Mean $\left(\mathrm{mg} \cdot \mathrm{L}^{-1}\right)$ & 1240.55 & 380 & 1293.33 & 373 & 391.25 & 1256 & 384 \\
\hline & Meancorrected & 1176.15 & - & 1228.93 & - & - & 1191.6 & - \\
\hline & SD & 11.28 & 0 & 28.87 & 7.07 & 1.06 & & \\
\hline & RSD & 0.91 & 0 & 2.23 & 1.90 & 0.27 & & \\
\hline & Bias & 7.87 & -2.81 & 12.46 & -4.60 & 0.06 & 9.22 & -1.79 \\
\hline & Bias corrected & 2.27 & - & 6.86 & - & - & 3.62 & - \\
\hline \multirow{6}{*}{$\begin{array}{c}\text { Ions }+\mathrm{D}^{\mathrm{a}}\left(150 \mathrm{~g} \cdot \mathrm{L}^{-1}\right) \\
+\mathrm{AA}^{\mathrm{a}}\left(4 \mathrm{~g} \cdot \mathrm{L}^{-1}\right)+\text { lipids }(40 \\
\left.\mathrm{g} \cdot \mathrm{L}^{-1}\right)+\mathrm{vit}^{\mathrm{a}}+\mathrm{TE}^{\mathrm{a}}\end{array}$} & Mean $\left(\mathrm{mg} \cdot \mathrm{L}^{-1}\right)$ & 1462.18 & 375.5 & 1516.67 & 362.5 & 374.25 & 1521 & 413 \\
\hline & Mean corrected & 1160.08 & - & 1214.57 & - & - & 1218.9 & - \\
\hline & SD & 16.63 & 0.71 & 51.32 & 10.61 & 3.89 & & \\
\hline & RSD & 1.14 & 0.19 & 3.38 & 2.93 & 1.04 & & \\
\hline & Bias & 27.15 & -3.96 & 31.88 & -7.29 & -4.28 & 32.26 & 5.63 \\
\hline & Bias corrected & 0.88 & - & 5.61 & - & - & 6 & - \\
\hline
\end{tabular}

${ }^{\mathrm{a}} \mathrm{D}=$ dextrose, $\mathrm{AA}=$ amino acids, $\mathrm{L}=$ lipids, vit = vitamins, $\mathrm{TE}=$ trace elements 
Table 7. Results obtained on parenteral nutrition mixes after ultrafiltration.

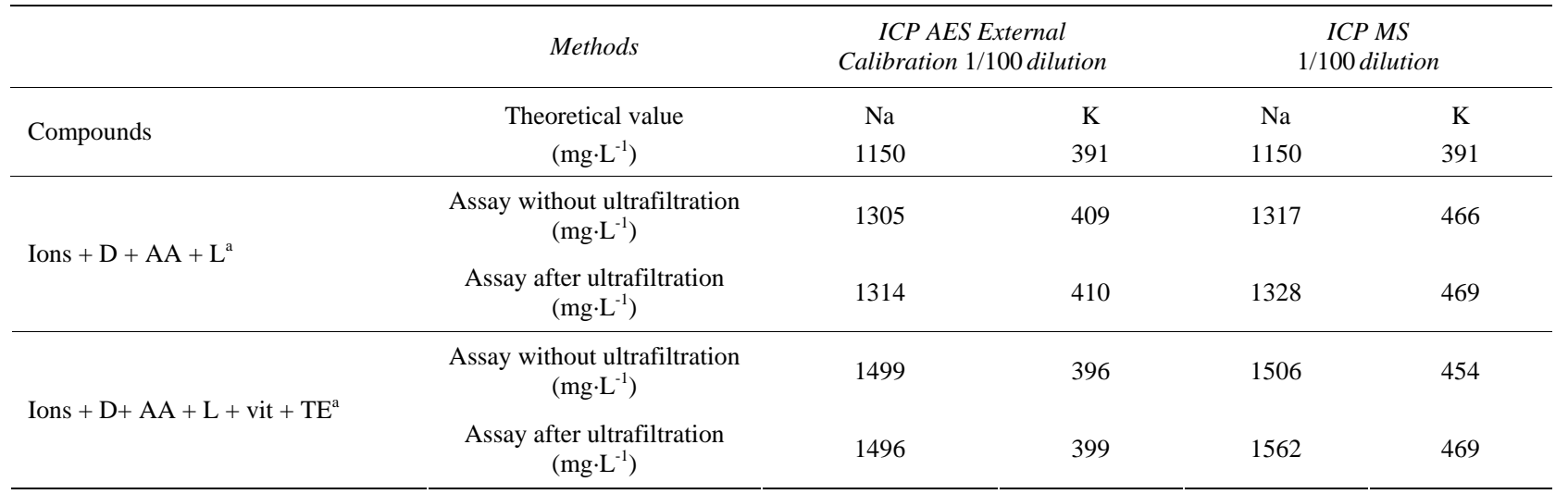

${ }^{\mathrm{a}} \mathrm{D}=$ dextrose, $\mathrm{AA}=$ amino acids, $\mathrm{L}=$ lipids, vit = vitamins, $\mathrm{TE}=$ trace elements

In our case, we recommend using the potassium assay as a quality marker because no supplies contain this electrolyte.

To reduce the risk and to improve the quality of compounding, we recommend using an automated compounding device instead of gravity-fill TPN system but, even in this case, the acceptance criterion for sodium and potassium determination was not $<10 \%$.

\section{Acknowledgements}

Françoise Lacroix and Severine Durand from EHESP/ LERES are gratefully acknowledged for their technical support throughout this study.

\section{References}

[1] P. Bonnabry, I. Cingria, F. Sadeghipour, H. Ing, C. Fonzo Christe and R. E. Pfizer, "Use of a Systematic Risk Analysis Method to Improve Safety in the Production of Paediatric Parenteral Nutrition Solutions,” Quality Safety Health Care, Vol. 14, No. 2, 2005, pp. 93-98. doi:org/10.1136/qshc.2003.007914

[2] "Safe Practices for Parenteral Nutrition Formulations," National Advisory Group on Standards and Practice Guidelines for Parenteral Nutrition, Journal Parenteral Enteral Nutrition, Vol. 22, No 3, 1998, pp. 49-66.

[3] H. Price, "New Technology Assists in Meeting ASPEN and ASHP Safety Guidelines to Minimize Total Parenteral Nutrition Compounding Errors," Journal of Parenteral Enteral Nutrition, Vol. 25, No 3, 2001, pp. 100-102.

[4] C. M. Crill, E. B. Hak and R. A. Helms, "Accuracy of Parenteral Nutrition Solutions Compounded with Automated Systems and by Hand," American Journal of HealthSystem Pharmacy, Vol. 62, No. 15, 2005, pp. 2345-2348. doi:org/10.2146/ajhp050322

[5] S. Nussbaumer, S. Fleury-Souverain, L. Bouchoud, S. Rudaz, P. Bonnabry and J.-L.Veuthey, "Determination of
Potassium, Sodium, Calcium and Magnesium in Total Parenteral Nutrition Formulations by Capillary Electrophoresis with Contactless Conductivity Detection,” Journal of Pharmaceutical and Biomedical Analysis, Vol. 53, 2010, pp. 130-136.

[6] C. St Laurent, L. Roulet and A. Dupuis, "Aspects Pharmacotechniques de la Nutrition Parentérale,"Actualités Pharmaceutiques Hospitalières, Vol. 14, 2008, pp. 44-50.

[7] H. Zegbeh, F. Pirot, T. Quessada,T. Durand, F .Vételé, A. Rose, V. Bréant and G.Aulagner, "Exactitude, Precision et Rapidité de Fabrication des Poches de Mélanges Nutritifs Parentéraux:Comparaison de Techniques Automatisée et Manuelle,” Ann Pharm Fr Journal, Vol. 69, 2011, pp. 38-44.

[8] P. Rucart, D. Balayssac, V. Sautou-Miranda, A. Boyer and J. Chopineau, "Enquête Nationale Sur Les Contrôles Des Mélanges Nutritifs Parentéraux Fabriqués Dans Les Pharmacies à Usage Intérieur des Centres Hospitaliers Universitaires," Nutrition Clinique et Métabolisme, Vol. 21, No. 2, 2007, pp. 47-48.

[9] D. J. Douglas, "Some Current Perspectives on ICP-MS," Canadian Journal of Spectroscopy, Vol. 34, No. 2, 1989, pp. 38-49. doi:org/10.1007/s00216-009-2658-3

[10] H. Xie, K. Huang, J. Liu, X. Nie and L. Fu "Determination of Trace Elements in Residual Oil by High-Resolution Inductively Coupled Plasma Mass Spectrometry,” Analytical Bioanalytical Chemistry, Vol. 393, No. 4, 2009, pp. 2075-2080. doi:org/10.1007/s00216-009-2658-3

[11] J. M. Mermet and E. Poussel, "Couplage plasma induit par haute fréquence-spectrométrie de masse,” Techniques de l'Ingénieur, Vol. TA4, 09, 1999, p. 2720.

[12] J. P. Cristol, B. Balint, B. Canaud and M. F. Daurés, "Méthodes de Dosage du Sodium Dans les Liquides Biologiques,” Néphrologie et Thérapeutique, Vol. 3, 2007, pp. S104-S111.

[13] G. B. Levy, "Determination of Sodium with Ion-Selective Electrodes,” Clinical Chemistry, Vol. 27, No. 8, 1981, pp. 1435-1438.

[14] H. T. Delves, "Atomic Absorption Spectroscopy in Clinical Analysis,” Annales of Clincal Biochemistry, Vol. 24, No. 
11, 1987, pp. 529-551.

[15] J. S. Fritz, "Recent Developments in the Separation of Inorganic and Small Organic Ions by Capillary Electrophoresis,” Journal of Chromatograph A, Vol. 884, 2000, pp. 261-275.

[16] A. J. Zemann, "Capacitively Coupled Contactless Conductivity Detection in Capillary Electrophoresis," Electrophoresis, Vol. 24, 2003, pp. 2125-2137.

[17] M. Koberda, M. Konkowski, P. Youngberg, W. R. Jones and A. Weston, "Capillary Electrophoretic Determination of Alkali and Alkaline-Earth Cations in Various Multiple Electrolyte Solutions for Parenteral Use," Journal of Chromatograph A, Vol. 602, No. 1-2, 1992, pp. 235-240.

[18] Q. Yang, M. Jimidar, T. P. Hamoir, J. Smeyers-Verbeke and D. L. Massart, "Determination of Alkali and Alkaline Earth Metals in Real Samples by Capillary Ion Analysis,” ournal of Chromatograph A, Vol. 673, No. 2, 1994, pp. 275-285.

[19] Vidal, "Monographies des Médicaments,” OVP- éditions du Vidal, Paris, 2010.

[20] RCP “Technical Information VINTENE ${ }^{\circledR}$," OVP-éditions du Vidal, Paris, 2010.
[21] M. A. Lester, C. Verdier, A. Jary and G. Burgot, “Analysis of Calcium in Total Parenteral Nutrition Bags: Critical Influence of the Ingredient,” European Journal of Hospital Pharmacy Science, Vol. 16, No. 2, 2010, pp. 48-52.

[22] Directive 2009/53/CE du Parlement Européen et du Conseil du 18 juin 2009. Journal Official Européen du 30 juin 2009.

[23] M. Feinberg, "LaboStat, Guide de Validation des MéThodes D’Analyse,” Lavoisier, Paris,Tec et Doc, 2009.

[24] E. Rozet, V. Wascotte, N. Lecouturier, V. Preat, W. Dewe, B. Boulanger and Ph. Hubert, "Improvement of the Decision Efficiency of The Accuracy Profile by Means of a Desirability Function for Analytical Methods Validation: Application to a Diacetyl-Monoxime Colorimetric Assay Used for the Determination of Urea in Transdermal Iontophoretic Extracts," Analytical Chemistry Acta, Vol. 591, No. 5, 2007, pp. 239-247.

[25] S. Ehling, S. Tefera, R. Earl and S. Cole, "Evaluation of Performance of Analytical Methods for Sodium in Foods with Low Sodium Concentration," Abstracts of paper, $238^{\text {th }}$ ACS National Meeting, Washington DC, United States, August 16-20, 2009. 